\title{
Oxygen metabolism of a fringing reef in French Polynesia
}

\author{
A. SOURNIA \\ Antenne du Muséum et de l'EPHE; Tabiti, \\ et \\ Muséum National d'Histoire Naturelle; Paris, France
}

EXTRAIT: Métabolisme de l'oxygène d'un récif frangeant de Polynésie Française. La production primaire d'une station située sur le récif frangeant de Moorea (îles de la Société, Polynésie Française) est déduite des variations nycthémérales des teneurs en oxygène dissous de l'eau de mer, aptès correction de diffusion. La production brute est ainsi de $19,2 \mathrm{~g} \mathrm{O}_{2} \mathrm{~m}^{-2}$ pour 24 heures, tandis que la production nette accuse un déficit de $3,1 \mathrm{~g}$ pendant la même période. Le milieu devient partiellement épuisé en oxygène dans le courant de la nuit. La courbe des accroissements horaires corrigés montre clairement une «dépression de midi». Simultanément, on mesurait les échanges d'oxygène sur des communautés benthiques enfermées dans des bocaux ou des sacs de plastique et maintenues in situ. $\mathrm{L}$ a production brute par jour était, dans ces conditions, de $10,1 \mathrm{~g} \mathrm{O}_{2} \mathrm{~m}^{-2}$ pour une communauté algale à dominance de Corallinacées (Neogoniolithon), 16,0 g pour une population mixte de Wurdemannia et Gelidium (Rhodophycées non calcaires), et de 3,0 g seulement pour un sable à Cyanophycées. Toutes les communautés étudiées présentaient, en 24 heures, un bilan d'oxygène positif. Les deux séries d'observations (métabolisme global d'une part, communautés isolées d'autre part) sont comparées et l'interprétation de telles données en termes d'«autotrophie» ou d'«hétérotrophie» est mise en doute.

\section{INTRODUCTION}

The simplicity and precision of dissolved oxygen measurements by either chemical or polarographic techniques, and the high metabolic activity usually observed in coralreef environments have made determinations of oxygen changes a widely used standard for studies on coral physiology and coral-reef productivity. Either of two approaches may be followed:

(a) Oxygen concentration is measured in the "open" seawater, without manipulating or enclosing any constituent of the ecosystem. Changes in space or time or in a space-time continuum allow total metabolism to be assessed, provided that some hypothesis or corrections are made with regard to physical processes. Pioneers in this method on coral-reef communities were SARGENT \& AUSTIN $(1949,1954)$; the method has since been subjected to several refinements and applications (see below).

(b) Time changes, usually over a few hours, are measured on enclosed organisms (whether individuals, colonies or communities). Some biological specificity is thus 
obtained; however, natural processes are modified to some extent by this "caging". A number of investigators have experimented on the coelenterate-xanthellae associations (e.g. TAYLOR, 1973). A few other studies were devoted to oxygen production and consumption by reef-building red algae (SARgENT \& Austin, 1954; MARSH, 1970; LITTLER, 1974; LitTLER \& DOTY, 1975), by calcareous green algae (ODum \& Odum, 1955; Hillis-Colinvaux, 1974), by sediments (Odum \& Odum, 1955; Sournia, 1976a) and by turtle grasses (QASIM et al., 1972). It may be noted that comparable experiments performed on phytoplankton (i.e.: the usual "light-and-dark bottle" method) result in very low and rather dubious rates, due to the scarcity of plankton in many of these waters (SARGENT \& AUSTIN, 1949; Jones, 1963; Kinsey, in press).

The two approaches are rarely used simultaneously, despite the evident interest of combining two complementary experimental strategies. Neither of these productivity methods has been employed, as yet, in any of the numerous reef areas of French Polynesia.

\section{STUDY AREA}

Moorea (Society Islands) is a high volcanic island (Tohivea Mt.: $1207 \mathrm{~m}$ ) surrounded by a fringing and barrier reefs system. The fringing and barrier reefs locally approach one another and even merge into a single unit. At Tiahura (Figs. 1-2), however, where the marine laboratory is located, a rather clear-cut distinction can be made; the lagoon there is about $800 \mathrm{~m}$ wide, although its depth does not exceed 6 meters.
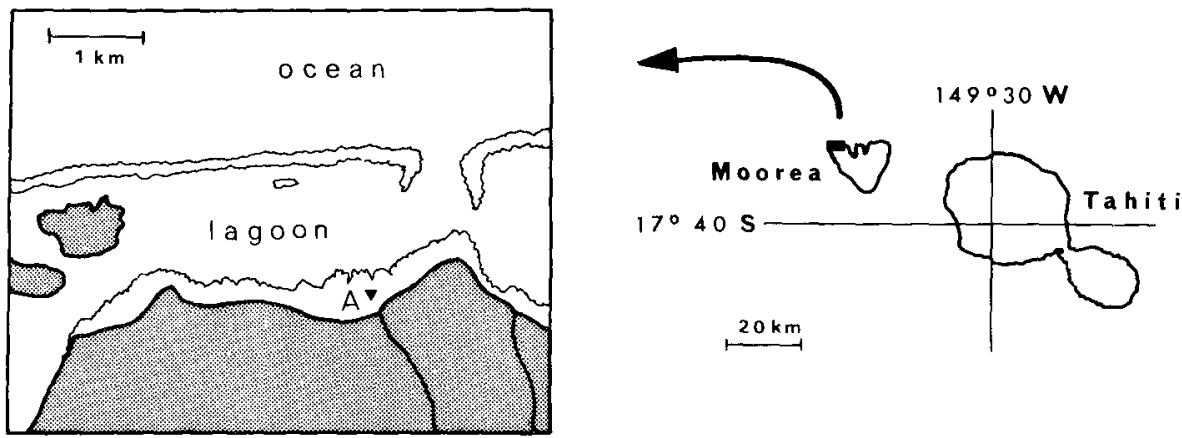

Fig. 1: Moorea Island and the study area

The circulation pattern is such that ocean surface water crosses the outer ridge, which is partly or wholly submerged according to tides; the water then sweeps over the barrier reef and a large part of the lagoon, and flows out through passes, one of which can be seen on Figures 1 and 2. Currents are more erratic on the fringing reef.

Studies were conducted during August 1975 in the fringing zone around point "A" (Fig. 1) where a variety of communities can be sampled within a restricted area: sands, coral heads, coralline algae and fleshy red algae. The average depth is about 


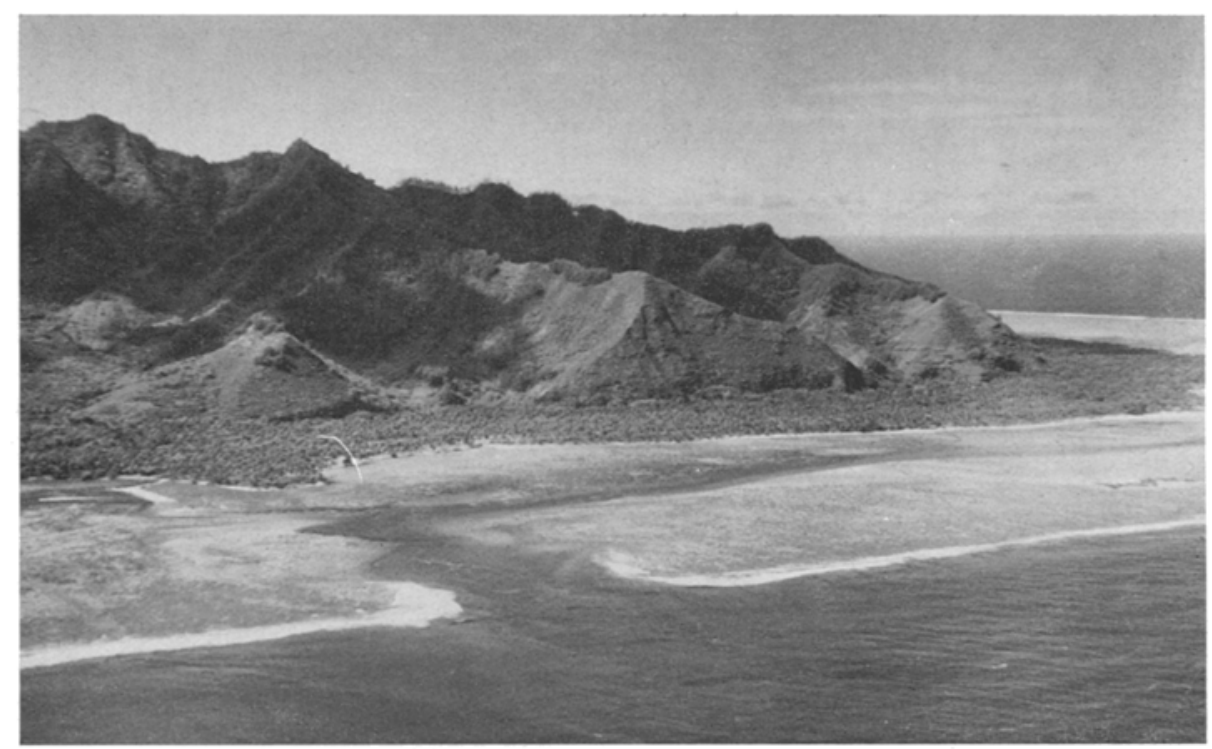

Fig. 2: Aerial view of the study area. (Photo: B. Salvat)

$0.75 \mathrm{~m}$. Tides tend to be semi-diurnal, but easterly winds and barometric changes over the lagoon result in an uneven pattern for both water level and tidal currents; the overall range of water level variations was only $28 \mathrm{~cm}$ over the two weeks studied. The temperature range during 24 hours was $22^{\circ}-27^{\circ} \mathrm{C}$.

Some data on phytoplankton and its primary production in this area were collected one year previous to the present study (SOURNIA \& RICARD, 1976).

\section{METHODS}

\section{Total metabolis m}

There are two major alternate strategies for assessing ecosystem metabolism from natural changes of oxygen concentrations in seawater, depending on whether a constant unidirectional flow (the "upstream-downstream" method) or a steady water mass (the single-station method) best describes the system in operation.

The second strategy has been followed here; its principles and techniques are described in several papers (Odum \& Hoskin, 1958; Odum et al., 1959; Krnsey, 1972; KINSEY, in press; SOURNIA, in press). In order to cancel out or integrate the short-term (hourly) and day-to-day variations of tidal level, tidal currents, winds and cloudiness, samples were taken at many times of day and night during 14 consecutive days; a total of 70 samples were collected. Occasionally, discrete samples were taken from the surface and from the bottom but, owing to shallowness and mixing, no stratification was ever encountered. Diffusion gains and losses were corrected according to ODum (1956) or Opum \& Hoskin (1958). 
All the oxygen analyses were performed polarographically with a Beckman ${ }^{\circledR}$ Fieldlab portable analyser which was calibrated against saturated seawater before each analysis or series of analyses. Measurements on duplicate samples varied by less than $0.1 \mathrm{mg} \mathrm{l}^{-1}$; otherwise the membrane and the electrolyte solution were renewed.

\section{Enclosed communities}

Pieces of algal communities were cut in situ with help of a plastic frame of known area $\left(64 \mathrm{~cm}^{2}\right)$. They were then enclosed, while still submerged, in 2-liter glass jars which were tightly closed with rubber caps. The adequate duration for experiments had been chosen beforehand from trial-and-error tests in order to get significant differences between initial and final concentrations while avoiding bubble formation; in both respects, 1- or 2-hour in situ exposures proved to be satisfactory. Successive experiments were repeated, as many as possible, from sunrise to sunset. From such series, daily production was obtained by summing up the successive values and "averaging" for the gaps between two of them. The same procedure was followed for respiration rates, except that jars were wrapped in dark plastic sheets and that exposures were run only once a day during 4-5 hours. As is usually assumed - albeit imprudently! - respiration rates are supposed to be constant throughout day and night.

Methods were about the same for sand communities. Since other aspects of the latter were also studied and some ecological peculiarities were revealed, these are reported on elsewhere (SOURNIA, 1976b).

Similar experiments were conducted on some coral species by J. JAUBERT (unpublished). Unfortunately, the problem of sampling a given and representative area of reef could not be solved at that time.

Oxygen analyses were carried out as described above.

\section{RESULTS}

\section{Total metabolis m}

Dissolved oxygen concentrations in the open water of the fringing zone vary quite dramatically during the course of 24 hours (Fig. 3). The usual range is from $3 \mathrm{mg} \mathrm{O} \mathrm{m}^{-1}$ at dawn to $10 \mathrm{mg}$ in the mid-afternoon; saturation percentages are 40 and $160 \%$ respectively. The steepness of the diel curve is remarkable, particularly during the early hours of the morning.

The importance of diel changes of dissolved oxygen concentrations in coral reef waters is rather well documented (references in Sournia, in press). However, one should consider the very low values which occur at Station A towards the end of the night; occasional measurements at another station showed values as low as $1.6 \mathrm{mg}$ $\mathrm{O}_{2} 1^{-1}$. There is no doubt that bottom fauna and flora would hardly withstand such conditions if they were maintained for a longer time. Even so, periodical oxygen depletion may be a significant factor in reef ecology. 


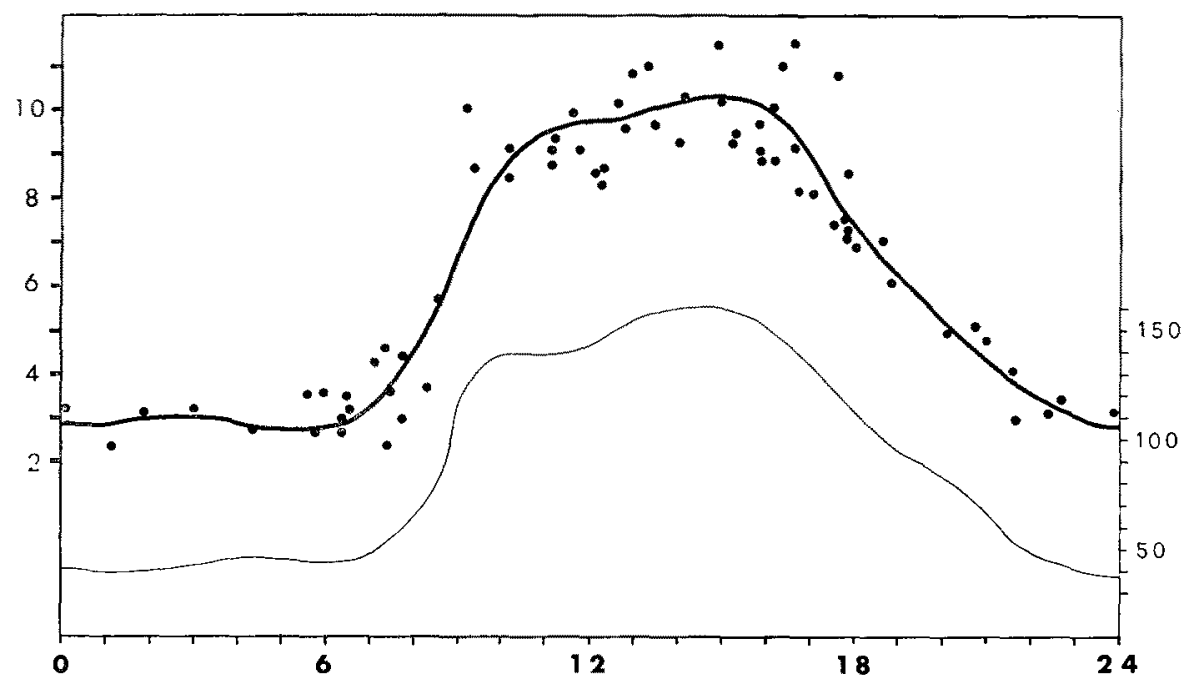

Fig. 3: Upper curve and left scale: dissolved oxygen concentrations ( $\mathrm{mg} \mathrm{O}_{2} \mathrm{l}^{-1}$ ) in the open water as a function of time at Station A; the curve was visually adjusted through the 70 points. Lower curve and right scale: saturation levels $(\%)$

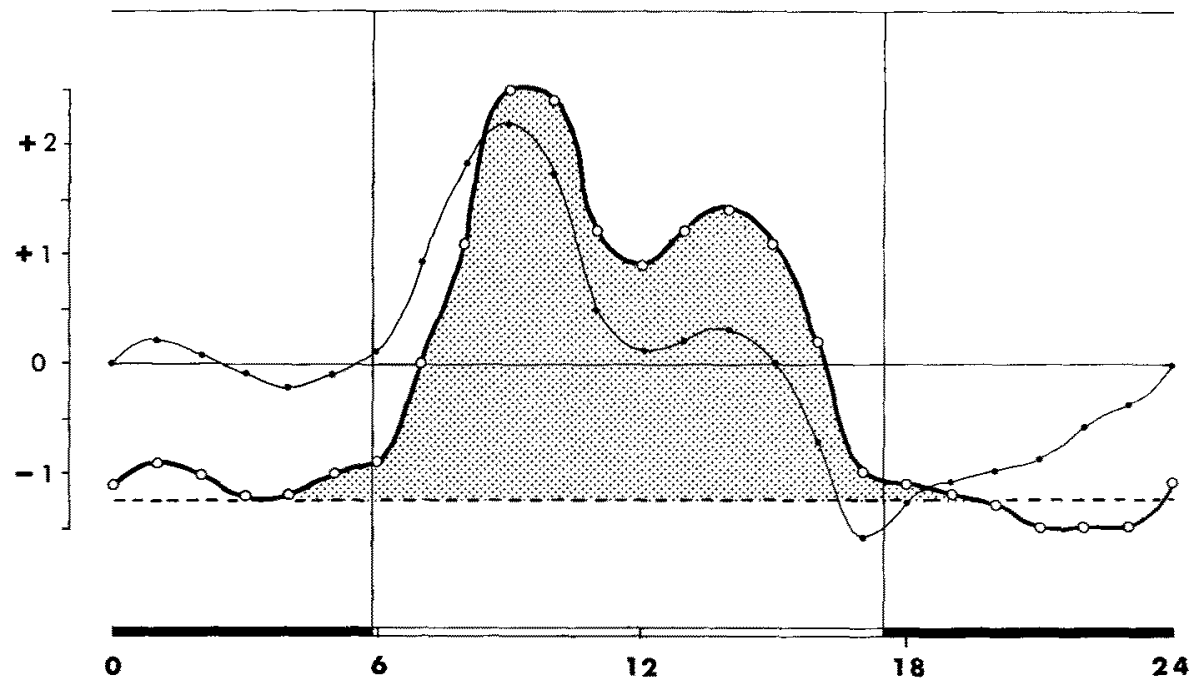

Fig. 4: Thin curve: hourly rates of dissolved oxygen concentrations $\left(\mathrm{mg} \mathrm{O}_{2} \mathrm{I}^{-1} \mathrm{~h}^{-1}\right.$ ) as deduced from the upper curve on Figure 3; note that it is mere chance if rates happened to be nil at O h precisely. Thick curve: hourly rates corrected for diffusion (same units). Dashed line: approximate respiration baseline. Shaded area: gross daily production. (Sunrise occurred a few minutes before 06.00 , sunset around 17.30 )

Apparent hourly rates, as deduced from Figure 3, are represented on Figure 4 (thin line). The diffusion constant was empirically estimated as $1.82 \mathrm{mg} \mathrm{O}_{2} \mathrm{l}^{-1} \mathrm{~h}^{-1}$, 
a rather high rate resulting from the strong winds which usually prevailed over the lagoon.

Final rates (Fig. 4, thick line) range approximately from -1.5 to $2.5 \mathrm{mg} \mathrm{O}_{2} 1^{-1} \mathrm{~h}^{-1}$. They show a peculiar trend, namely a secondary minimum around noon; though such a feature has not been reported so far from this type of data, it can be easily related to the well-known "midday depression" of photosynthesis (e.g. Talling, 1961).

Daily production and consumption rates, as deduced from the latter curve, are the following: gross production $=19.2 \mathrm{~g} \mathrm{O}_{2} \mathrm{~m}^{-2}(24 \text {-hour day })^{-1}$ and respiration $=$ $22.3 \mathrm{~g}$ (same units).

Thus net production results in a deficit of $3.1 \mathrm{~g} \mathrm{O}_{2}$. In other words, this part of the reef consumes slightly more oxygen than it produces daily.

For the sake of comparisons, the above figures may be converted in carbon units, on the reasonable assumption that photosynthetic quotient does not differ from unity (SMTTH \& MARsh, 1974). Then gross production amounts to $7.2 \mathrm{~g} \mathrm{C} \mathrm{m}^{-2} \mathrm{day}^{-1}$ and enters the range of data published up to now for reef ecosystems when studied by the same method (data and references may be found in SMITH, 1974, or in Sournia, in press). As for net production, which exhibits in the present case a loss of $1.2 \mathrm{~g} \mathrm{C} \mathrm{m}^{-2}$ day $^{-1}$, let us note that it is reported in the literature to be either slightly positive (e.g. KoHn \& Helfrich, 1957), or non significant (e.g. Odum \& Odum, 1955) or even negative (Gordon \& KelLY, 1962).

\section{Enclosed communities}

The "Neogoniolithon community", as reported in Table 1, is an algal assemblage dominated by the coralline alga Neogoniolithon frutescens (Foslie) Setchell \& MASON. The main associated species are the green alga, Valonia utricularis AGARDH, and the non-calcareous red algae, Wurdemannia miniata (LAmouroux) FELdmann \& HAMEL and Gelidium sp.; the biomass of other constituents such as the coralline alga Jania sp. or the gastropod Ceritbium alveolus Hombron \& JACQUnNot is quantitatively negligible. Daily gross production amounts to $10.1 \mathrm{~g} \mathrm{O}$ (or $3.8 \mathrm{~g} \mathrm{C}$ ) per square meter, of which about half is consumed by respiration, so that a daily net production of $5.2 \mathrm{~g} \mathrm{O}_{2}$ (or $2.0 \mathrm{~g} \mathrm{C}$ ) is observed.

Net production per square meter of reef may be chosen as a common basis for comparing the above figures with the few available data on productivity of coralline algae. The present rate thus appears to be half-way between those of MARSH (1974) or Littler \& Doty (1975) on the one hand, and those of Littrler (1974) on the other, i.e.: $0.66,0.5$ and $5.7 \mathrm{~g} \mathrm{C} \mathrm{m}^{-2} \mathrm{day}^{-1}$, respectively. All these authors, including myself, experimented on enclosed communities. The alternative oxygen method, that of the "upstream-downstream" stations, was worked out by SMITH \& MArsh (1974) along an algal transect at Enewetak; as deduced from their tables, net production there ranged from 4 to $7 \mathrm{~g} \mathrm{C} \mathrm{m}^{-2}$ day $^{-1}$.

Another algal population is characteristic of Moorea fringing reef. It consists chiefly of the two above-mentioned, filamentous red algae, Wurdemannia miniata and Gelidium sp. The gross production of this community is about 1.5 times more than that 
of the former one (Table 1). Respiration is only slightly higher, so the resulting net production amounts to $9.8 \mathrm{~g} \mathrm{O}_{2}$ (or $3.7 \mathrm{~g} \mathrm{C}^{-2} \mathrm{~m}^{-2}$ day $^{-1}$.

Closest to the shore is the sandy area (Sournia, 1976b). Its photosynthetic standing stock consists mostly of Oscillatoria limosa AgArDH, a blue-green alga which is heavily cropped by the holothurian Halodeima atra (JAEGER). Oxygen production here is substantially lower than that of the two algal communities (Table 1). In order to determine the effects of oxygen consumption by the holothurians, experiments were conducted on specimens enclosed in glass jars, as previously described. Animals in such conditions do not feed nor move, so respiration estimates must be minimal. It was found that an "average" Halodeima of $50 \mathrm{~g}$ fresh weight respires about $0.016 \mathrm{~g} \mathrm{O}_{2}$ per day. Considering the huge local crop of holothurians, it thus appears that they will consume a significant part of the slight oxygen excess originating from the sands $\left(1.5 \mathrm{~g} \mathrm{O}_{2} \mathrm{~m}^{-2}\right.$ day $\left.^{-1}\right)$.

About corals and their symbiotic zooxanthellae, all we can report here is that, on a 24-hour basis, oxygen production significantly exceeded respiration losses ( $\mathrm{J}$. JAUBERT, personal communication). The extensive literature on this subject is reviewed by SOURNIA (in press).

\section{CONCLUDING REMARKS}

Photosynthetic and respiratory rates are summarized in Table 1. Since all of them are expressed per unit area of reef and were obtained by in situ experiments, they allow some comparisons to be made.

First, it can be seen that gross production rates do not differ very much from each other - nor do they depart from the usual range of coral reef production - except for sands, the production of which is the lower by about fourfold. Sands were also shown

\section{Table 1}

Some characteristic values of oxygen production and consumption per unit reef area on Moorea fringing reef. "Day" and "daily" stand for a full 24-hour period. Daily rates are converted in carbon assuming that photosynthetic quotient equals unity

\begin{tabular}{|c|c|c|c|c|}
\hline $\begin{array}{l}\text { Respiration and } \\
\text { production rates }\end{array}$ & $\begin{array}{c}\text { Total } \\
\text { metabolism } \\
\text { (integrated } \\
\text { over } 14 \text { days) }\end{array}$ & $\begin{array}{l}\text { Neogonio- } \\
\text { lithon } \\
\text { community } \\
\text { (14 ex- } \\
\text { periments) }\end{array}$ & $\begin{array}{l}\text { Non- } \\
\text { calcareous } \\
\text { red algae } \\
\text { (15 ex- } \\
\text { periments) }\end{array}$ & $\begin{array}{c}\text { Sands } \\
\text { (14 ex- } \\
\text { periments) }\end{array}$ \\
\hline $\begin{array}{l}\text { Net production around noon } \\
\mathrm{mg} \mathrm{O} \mathrm{O}_{2} \mathrm{~m}^{-2} \mathrm{~h}^{-1}\end{array}$ & $500-800$ & 868 & 1005 & 266 \\
\hline $\begin{array}{l}\text { Mean hourly respiration } \\
\text { mg O } \mathrm{O}_{2} \mathrm{~m}^{-2} \mathrm{~h}^{-1} \\
\text { Daily gross production }\end{array}$ & 620 & 203 & 258 & 58 \\
\hline $\mathrm{g} \mathrm{O}_{2} \mathrm{~m}^{-2}$ day $^{-1}$ & 19.2 & 10.1 & 16.0 & 3.0 \\
\hline$\underset{\mathrm{g} \mathrm{C} \mathrm{m}}{-2}$ day $^{-1}$ & 7.2 & 3.8 & 6.0 & 1.1 \\
\hline $\begin{array}{l}\mathrm{g} \mathrm{O}_{2} \mathrm{~m}^{-2} \mathrm{day}^{-1} \\
\mathrm{~g} \mathrm{C} \mathrm{m}^{-2} \mathrm{day}^{-1}\end{array}$ & $\begin{array}{l}-3.1 \\
-1.2\end{array}$ & $\begin{array}{l}5.2 \\
2.0\end{array}$ & $\begin{array}{l}9.8 \\
3.7\end{array}$ & $\begin{array}{l}1.5 \\
0.6\end{array}$ \\
\hline
\end{tabular}


to be less productive than the other parts of the reef in the studies of ODUM \& ODJM (1955), MARSh (1974), and Kinsey (in press).

Respiration proceeds at about the same rate in the two algal populations and at a substantially lower rate in sands. It is far more rapid for the whole ecosystem.

As a consequence of the two above trends, differences are noted among net daily rates. There is an excess production of oxygen in each of the discrete communities (though it differs from one to another); the same feature is observed qualitatively for the algal-coral associations, although numerical assessment could not be obtained. Yet the overall balance shows a deficit.

The above-mentioned communities represented visually the 4 main benthic compartments of the ecosystem, so one could invoke plankton as a clue for elucidating the discrepancy. This explanation, however, would fail, owing to the ancillary data which follow. On the one hand, phytoplankton production was measured simultaneously by the ${ }^{14} \mathrm{C}$ method and was as low as $0.006 \mathrm{~g} \mathrm{C} \mathrm{m}^{-2}$ day ${ }^{-1}$; one year previously, it had been about the same, i.e. $0.004 \mathrm{~g}$ (SournIa \& Ricard, 1976). On the other hand, biological oxygen demand in August 1975 was only $0.92 \mathrm{mg} \mathrm{O}_{2} \mathrm{l}^{-1}$. Thus, as often encountered in coral environments, plankton life and suspended matter quantitatively account for only a minute contribution in total metabolism.

Where, then, is the truth, and which is the right approach: enclosing the organisms or scrutinizing the open water?

As a matter of fact, such questions seem to be unrealistic. "Techniques" such as the polarographic and the chemical ones for oxygen analysis can be compared with respect to precision, accuracy, practicability and so on. But, as far as primary production and integrated biological processes are concerned, one could hardly expect to find two "methods" which would aim to measure the same phenomenon and would do it within the same theoretical assumptions and under the same experimental conditions. Hence the risks of relying on a single approach only, and the advantages of combining two or more of them, particularly when dealing with such complex ecosystems as coral reefs.

Oxygen balance in coral-reef environments has long been interpreted in terms of autotrophy and heterotrophy. According to the present set of data, it could be concluded that each of the four benthic communities under study is "autotrophic" while the whole fringing reef behaves "heterotrophically". Both conclusions may well be true: plant-dominated populations produce more oxygen than they consume, while plant and animal respiration together with decomposition processes in the benthos, plankton and nekton results in a net oxygen consumption by the whole area - for which the barrier reef or the ocean may compensate.

A final comment: "autotrophy" (greek: "self-feeding") is a question of what an organism or a population feeds on. There are, living on earth, many creatures which might consider themselves fortunate if struggling for oxygen only could bestow on them autotrophy. In these shallow, well mixed waters, oxygen supply may not be a prime necessity, though the possibility that it could become partially depleted at night should not be overlooked. Clearly, trophic aspects regarding carbon, nitrogen, phosphorus and so on, in such highly productive ecosystems, are more challenging. 
This formal criticism about "oxygen autotrophy" does not affect at all the use of oxygen measurements as a handy and reliable tool in studies of coral reef productivity.

\section{SUMMARY}

1. Primary production was estimated during August 1975 at one station on the fringing reef of Moorea (French Polynesia) by following the diel changes of dissolved oxygen concentrations in the open water and correcting them for diffusion. Daily (24-hour) gross production amounted to $19.2 \mathrm{~g} \mathrm{O}_{2} \mathrm{~m}^{-2}$ while net production showed a deficit of $3.1 \mathrm{~g} \mathrm{O}_{2} \mathrm{~m}^{-2}$. Oxygen depletion occurs to a considerable extent during the night. Hourly rates provide evidence for a midday depression of photosynthesis.

2. Oxygen exchanges were also measured on benthic communities enclosed in glass jars or plastic bags. Gross production was $10.1 \mathrm{~g} \mathrm{O}_{2} \mathrm{~m}^{-2}$ day-1 for an algal community dominated by Corallinaceae, $16.0 \mathrm{~g}$ for two non-calcareous red algae, and $3.0 \mathrm{~g}$ only for sands. All benthic communities produced more oxygen in a 24 -hour period than they consumed.

3. The two series of observations are compared. The significance of such data with respect to "autotrophy" or "heterotrophy" is criticized.

Acknowledgements. Thanks are expressed to Dr. B. SALVAT, Director of the "Antenne du Muséum et de l'EPHE", for working facilities at Moorea. Financial support for this work was granted by the "Territoire de la Polynésie Française". The algae were identified by Drs. F. Ardré and M. Lemorne (Muséum, Paris). Prof. S. V. Smrth (University of Hawaii) commented on the manuscript and corrected it for style.

\section{LITERATURE CITED}

Gordon, M. S. \& Kelly, H. M., 1962. Primary productivity of a Hawaiian coral reef: a critique of flow respirometry in turbulent waters. Ecology 43, 473-480.

Hilirs-Colinvaux, L., 1974. Productivity of the coral reef alga Halimeda (order Siphonales). In: Proceedings of the second international symposium on coral reefs. Ed. by A. M. Cameron, B. M. Campbell, A. B. Cribb, R. Endean, J. S. Jell, O. A. Jones, P. Mather \& F. H. TALвот. Great Barrier Reef Conmittee, Brisbane, 1, 35-42.

JonEs, J. A., 1963. Ecological studies of the southeastern Florida patch reefs. I. Diurnal and seasonal changes in the environment. Bull. mar. Sci. 13, 282-307.

KinsEY, D. W., 1972. Preliminary observations on community metabolism and primary productivity of the pseudo-atoll reef at One Tree Island, Great Barrier Reef. In: Proceedings of the symposium on corals and coral reefs. Ed. by C. Mukundan \& C.S. G. Pillai. Marine Biological Association of India, Cochin, 13-32.

- Community studies; B - Still waters. In: Handbook for coral reef research methods. Ed. by D. R. Stoddart \& R. E. Johannes. Unesco monographs on oceanographic methodology. Unesco Press, Paris (in press).

Konn, A. J. \& Helfrich, P., 1957. Primary organic productivity of a Hawaiian coral reef. Limnol. Oceanogr. 2, 241-251.

Lirtler, M. M., 1974. The productivity of Hawaiian fringing-reef crustzone Corallinaceae and an experimental evaluation of production methodology. Limnol. Oceanogr. 18, 946-952. 
— \& Doty, M. S., 1975. Ecological components structuring the seaward edges of tropical Pacific reefs: the distribution, communities and productivity of Porolithon. J. Ecol. 63, 117-129.

Marsh, J. A. Jr., 1970. Primary productivity of reef-building calcareous red algae. Ecology 51, 255-263.

- 1974. Preliminary observations on the productivity of a Guam reef flat community. In: Proceedings of the second international symposium on coral reefs. Ed. by A. M. Cameron, B. M. Campbell, A. B. Cribb, R. Endean, J. S. Jell, O. A. Jones, P. Mather \& F. H. Тацвот. Great Barrier Reef Committee, Brisbane, 1, 139-145.

Odum, H. T., 1956. Primary production in flowing waters. Limnol. Oceanogr. 1, 102-117.

- Burkholder, P. \& Rivero, P., 1959. Measurements of productivity of turtle grass flats, reefs and the Bahia Fosforescente of southern Puerto Rico. Publs Inst. mar. Sci. Univ. Texas 6, 159-170.

- \& Hoskin, C. M., 1958. Comparative studies on the metabolism of marine waters. Publs Inst. mar. Sci. Univ. Texas 5, 16-46.

- \& ODum, E. P., 1955. Trophic structure and productivity of a windward coral reef community on Eniwetok atoll. Ecol. Monogr. 25, 291-320.

QAsim, S. Z., Bhattathiri, P. M. A. \& ReDdy, C. V. G., 1972. Primary production of an atoll in the Laccadives. Int. Revue ges. Hydrobiol. 57, 207-226.

Sargent, M. C. \& Austin, T. S., 1949. Organic productivity of an atoll. Trans. Am. geophys. Union 30, 245-249.

- - 1954. Biologic economy of coral reefs. In: Bikini and nearby atolls. Part. 2. Oceanography (biologic). Prof. Pap. U.S. geol. Surv. 260 (E), 293-300.

Smith, S. V., 1974. Coral reef carbon dioxide flux. In: Proceedings of the second international symposium on coral reefs. Ed. by A. M. Cameron, B. M. Campbeld, A. B. Cribb, R. Endean, J. S. Jell, O. A. Jones, P. Mather \& F. H. Talbot. Great Barrier Reef Committee, Brisbane, 1, 77-85.

- \& Marsh, J. A. Jr., 1974. Organic carbon production on the windward reef flat of Eniwetok atoll. Limnol. Oceanogr. 18, 953-961.

Sournia, A., 1976a. Primary production of sands in the lagoon of an atoll and the role of foraminiferan symbionts. Mar. Biol. 37, 29-32.

- 1976b. Ecologie et productivité d'une Cyanophycée en milieu corallien: Oscillatoria limosa Agardh. Phycologia 15, 363-366.

- Analyse et bilan de la production primaire dans les récifs coralliens. Annls Inst. océanogr., Monaco (in press).

- \& Ricard, M., 1976. Phytoplankton and its contribution to primary productivity in two coral reef areas of French Polynesia. J. exp. mar. Biol. Ecol. 21, 129-140.

Talling, J. F., 1961. Photosynthesis under natural conditions. A. Rev. Pl. Physiol. 12, 133-154.

TAYLOR, D. L., 1973. Symbiotic pathways of carbon in coral reef ecosystems. Present status and future prospects. Helgoländer wiss. Meeresunters. 24, 276-283.

Author's address: Dr. A. SourniA

Dynamique des populations aquatiques

Muséum National d'Histoire Naturelle

43 , rue Cuvier

F-75231 Paris 05

France 